\title{
SEJARAH PERKEMBANGAN BAHASA ARAB DI PULAU SUMATERA
}

\section{Budi Santoso}

STAI Ali bin Abi Thalib Surabaya

budisantoso5731@stai-ali.ac.id

\begin{abstract}
الملنخص
اللغة العربية هي لغة القرآن وأحاديث النبي صلى الله عليه و سلم، وهي إحدى اللغات الرسمية في العالم. انتشر اللغة العربية بفضل الله مع انتشار الإسلام. المسلون في كل زمان ومكان يتعلمون القرآن. عندما دخل ألإسلام في إندونسيا عن طريق التجار، دخلت اللغة العربية في ذلك البلد. في أندونوسيا جزر كثيرة، هناك جاوى وكليمانتان وسولاويسي و بابووا ، وسوماترا وغير ذلك. انتشرت اللغة العربية في سوماترا منذ زمن قديم. ومما يدل على انتشارها وجود مساجد و مصليات و بيوت تدرس فيها القرآن. المسلمون يتعلمون القرآن من ويتعرفون على حروفه. وكانوا يقلدون أصوات مشايخهم • ومن حلقات القرآن التي تدرس في المساجد والبيوت أنشأت المعاهد الإسلامية والمدارس الدينية. جاء المسلمون إلى المعاهد لتعلم العلوم افسلامية واللغة العربية. الطلاب يدرسون اللغة العربية عن طريق كتب صفراء ( وهي كتب أوراقها لونها صفراء). وتللك الكتب كتبت باللغة العربية. الطلاب يفتخرون بدراسة تلك الكتب لأفمم يفرحون بدراستهم اللغة العربية وفهمهم ماكتبه الأساتذة في تلك الكتب. أما طرق تدريس اللغة الغربية المتخدمة لتعليم الغة العربية منها : باندوج ، سوروج، حلقة ، حوار ، المشاورة وبحث المسائل.
\end{abstract}

Kata Kunci: Bahasa Arab, Sumatra, Kitab Kuning

\section{PENDAHULUAN}

Sejarah merupakan ilmu yang mempelajari tentang kejadian atau peristiwa masa lampau, dengan mempelajari sejarah dapat memberikan kepada pembaca sendiri tentang apa yang terjadi dimasa lampau. Dimana kejadian-kejadian dimasa lampau tersebut dapat memberikan pengalaman dan wawasan yang telah terjadi dimasa tersebut.

Bahasa Arab adalah bahasa yang sangat mulia dan memiliki keistemewaan yang sangat banyak dibandingkan dengan bahasa lainnya. Bahsa Arab sebagai bahasa agama islam adalah sebuah fakta yang tidak dapat dipungkiri. Karena dengan Bahasa Arablah agama ini ditegakkan, dan al-qura'an diturunkan. Bahsa Arab adalah bahsa yang memiliki keunggulan, keberagaman serta kekayaan perbendaharaan kosakata yang sangat banyak dibandingkan dengan bahsa lainnya. Bahsa Arab telah menjadi pengantar resmi masyarakat indonesia, hususnya di pulau Sumatera, ditemukan banyak kata sarapan bahasa Arab yang terdapat dalam bahasa Indonesia

Hampir setiap lembaga pendidikan sejak zaman dahulu kala berbasis keagamaan atau madrasah di Indonesia menerapkan pembelajaran bahasa Arab secara profesional dan intensif yang disandarkan pada analisis kebutuhan dalam pembelajaran bahasa Arab. 
Khususnya di pulau sumatera bahasa Arab sangat berembang pesat sejak dahulu, dan perkembangan bahasa Arab berpusat di Aceh darusalam karena disitulah pertamakali islam masuk di pulau Sumatera.

Disini penulis akan memaparkan bagaimana sejarah perkembangan bahasa Arab di pulau Sumatera. Dengan demikian pemembaca makalah ini dapat mengetahui bagaimana sejarah perkembangan bahasa Arab di pulau Sumatera dan Indonesia.

\section{PEMBAHASAN}

\section{A. Definisi Bahasa Arab}

Bahasa Arab bila dilihat dari pengertian secara umum dapat ditinjau dari definisi umum bahasa dari berbagai daerah. Bahasa dalam bahasa Indonesia sama dengan istilah "taal", dalam bahasa Belanda, dalam bahasa Ingggris "language", "bhasa” dalam bahasa Sangsekerta dan "لغة" dalam bahasa Arab.

Dari istilah tersebut pastilah memiliki karakteristik tersendiri antara satu dengan yang lainnya.

Kekhususan ini didasarkan pada lingkungan perkembangan bahasa tersebut dalam kehidupan masyarakat. Sebenarnya bahasa adalah suatu istilah untuk menyebutkan suatu unsur kebudayaan dalam suatu masyarakat yang memiliki aspek yang sangat luas. Sehingga bahasa merupakan persepektif yang sangat luas dan tidak dibatasi.

Sedangkan dalam bahasa Arab kata "لغة" berawal dari kata "لغا" yang artinya berbicara.

Dari definisi bahasa yang didasarkan pada berbagai bangsa tersebut, dapat ditarik kesimpulan bahwa sifat umum adalah suatu lambang yang berwujud bunyi yang keluar dari mulut dengan bentuk sedemikian rupa hingga bunyi itu mengandung atau mempunyai arti tertentu yang digunakan oleh segolongan masyarakat tertentu untuk berkomunikasi dan interaksi. ${ }^{1}$

\section{B. Sejarah perkembangan bahasa Arab di pulau Sumatera}

\section{Sejarah asal usul pulau Sumatera}

Para musafir Arab menyebut Sumatera dengan nama "Serendib" (tepatnya: "Suwarandib"), transliterasi dari nama Suwarnadwipa. Abu Raihan Al-Biruni, ahli geografi Persia yang mengunjungi Sriwijaya tahun 1030, mengatakan bahwa negeri Sriwijaya terletak di pulau Suwarandib. Namun ada juga orang yang mengidentifikasi Serendib dengan Srilangka, yang tidak pernah disebut Suwarnadwipa.

Di kalangan bangsa Yunani purba, Sumatera sudah dikenal dengan nama Taprobana. Nama Taprobana Insula telah dipakai oleh Klaudios Ptolemaios, ahli geografi Yunani abad kedua Masehi, tepatnya tahun 165, ketika dia menguraikan daerah Asia Tenggara dalam karyanya Geographike Hyphegesis. Ptolemaios menulis bahwa di pulau Taprobana terdapat negeri Barousai. Mungkin sekali negeri yang dimaksudkan adalah Barus di pantai barat Sumatera, yang terkenal sejak zaman purba sebagai penghasil kapur barus.

Naskah Yunani tahun 70, Periplous tes Erythras Thalasses, mengungkapkan bahwa Taprobana juga dijuluki chryse nesos, yang artinya 'pulau emas'. Sejak zaman purba para pedagang dari daerah sekitar Laut Tengah sudah mendatangi Nusantara, terutama Sumatera. Di samping mencari emas, mereka mencari kemenyan (Styrax sumatrana) dan kapur barus (Dryobalanops aromatica) yang saat itu hanya ada di Sumatera. Sebaliknya, para pedagang Nusantara pun sudah menjajakan komoditi mereka sampai ke Asia Barat dan Afrika Timur, sebagaimana tercantum pada naskah Historia Naturalis karya Plini abad pertama Masehi.

Dalam kitab umat Yahudi, Melakim (Raja-raja), fasal 9, diterangkan bahwa Nabi Sulaiman a.s. raja Israil menerima 420 talenta emas dari Hiram, raja Tirus yang menjadi bawahan beliau. Emas itu didapatkan dari negeri Ofir. Kitab Al-Qur’an, Surat Al-Anbiya’ 81,

\footnotetext{
${ }^{1}$ Ulin Nuha, Ragam Metodelogi Dan Media Pembelajaran Bahasa Arab (Yogyakarta: Diva Perss, 2016$), 23$.
} 
menerangkan bahwa kapal-kapal Nabi Sulaiman berlayar ke "tanah yang Kami berkati atasnya”.

Banyak ahli sejarah yang berpendapat bahwa negeri Ophir itu terletak di Sumatera (Gunung Ophir di Pasaman Barat, Sumatera Barat yang sekarang bernama Gunung Talamau?). Perlu dicatat, kota Tirus merupakan pusat pemasaran barang-barang dari Timur Jauh. Ptolemaios pun menulis Geographike Hyphegesis berdasarkan informasi dari seorang pedagang Tirus yang bernama Marinus. Dan banyak petualang Eropa pada abad ke-15 dan ke-16 mencari emas ke Sumatera dengan anggapan bahwa di sanalah letak negeri Ofir Nabi Sulaiman a.s. ${ }^{2}$

Kata yang pertama kali menyebutkan nama Sumatra berasal dari gelar seorang raja Sriwijaya Haji (raja) Sumatrabhumi ("Raja tanah Sumatra"), berdasarkan berita China ia mengirimkan utusan ke China pada tahun 1017. Pendapat lain menyebutkan nama Sumatera berasal dari nama Samudera, kerajaan di Aceh pada abad ke-13 dan abad ke-14. Para musafir Eropa sejak abad ke-15 menggunakan nama kerajaan itu untuk menyebut seluruh pulau. Sama halnya dengan pulau Kalimantan yang disebut Borneo, dari nama Brunai, daerah bagian utara pulau itu yang mula-mula didatangi orang Eropa. Demikian pula pulau Lombok tadinya bernama Selaparang, sedangkan Lombok adalah nama daerah di pantai timur pulau Selaparang yang mula-mula disinggahi pelaut Portugis. ${ }^{3}$

Aceh merupakan daerah yang pertama menerima Islam di nusantara. Dalam sejarah perkembangan Islam di nusantara, kerajaan Islam Peureulak merupakan kerajaan Islam yang pertama, kemudian baru muncul kerajaan-kerajaan lain yang sangat berjasa besar dalam mengembangkan Islam di wilayah Asia tenggara.

Setelah Perlak dalam perkembangan selanjutnya, kerajaan Aceh Darussalam mencapai masa kejayaannya, kemegahan, kemakmuran, dan kedamaian selalu tercipta dalam kehidupan sehari-hari, terutama pada masa sultan Iskandar Muda, sultan ini telah menjadikan Aceh sebagai pusat berbagai kegiatan kerajaan Aceh, baik yang berhubungan dengan kegiatan dalam negeri maupun luar negeri.

Masa Sultan Iskandar muda memerintah Aceh digambarkan dalam rentetan sejarah sebagai masa sadar beragama dan mengamalkan ajarannya. Pada masa ini pula, dalam sejarah perkembangan kerajaan Aceh Darussalam dikatakan bahwa ilmu pengetahuan berkembang dengan cukup pesat, sultan berusaha memajukan berbagai sektor pendidikan, antara lain pendidikan agama, pendidikan bahasa, pendidikan ilmu hukum, seni budaya, militer dan olah raga. Di saat sultan Iskandar muda memegang tampuk kekuasaan Aceh merupakan pusat pendidikan, sehingga Aceh dapat mencapai puncak kejayaan. Agama Islam benar-benar meresap ke dalam jiwa pemeluknya, sehingga tidak berlebihan kiranya Aceh mendapat julukan serambi Mekkah.

Para ahli sejarah lokal maupun internasional telah menulis dalam karya mereka tentang sejarah Aceh, bahwa pada masa Sultan Iskandar Muda memegang kekuasaan, Aceh adalah pusat Ilmu pendidikan dan kerajaan Aceh merupakan kerajaan yang masyhur di antara kerajaan-kerajaan lain. ${ }^{4}$

Kemajuan bidang pendidikan, ekonomi, dan agama di raih melalui lembaga pendidikan meunasah. Lembaga ini bukan hanya tempat ibadah semata melainkan juga sebagai pusat yang multi-fungsi, baik untuk pendidikan, musyawarah, kenduri, mengadili pelanggar hukum, menerapkan hukuman, pos keamanan, dan tempat istirahat masyarakat. Kemajuan dan

${ }^{2}$ Sanusi Pane, Sejarah Perkembangan Indonesia, (Jakarta: Balai Pustaka, 1995), 76.

${ }^{3}$ Lukman Ali, Kamus Besar Bahasa Indonesia,Jilid II, (Departemen P \& K RI. Jakarta: Balai Pustaka, 1994$), 40$.

${ }^{4}$ Sanusi Pane, Sejarah Perkembangan Indonesia, (Jakarta: Balai Pustaka,1995), 150 
kejayaan kerajaan Aceh tidak bisa dipisahkan dari kemajuan pendidikannya, karena pendidikanlah yang menentukan kejayaan dan kemakmuran suatu bangsa. Untuk meningkatkan pendidikan agama dalam kerajaan Aceh, para Sultan Aceh telah menempuh berbagai kebijakan antara lain sebagaimana yang dilakukan oleh sultan Iskandar Muda, sebagaimana yang termaktub dalam Qanun Meukuta Alam, yakin menyusun lembagalembaga pendidikan dalam tiga bidang dan tugas khusus: masalah pendidikan, pengajaran dan pengembangan Ilmu pengetahuan. Lembaga-lembaga pendidikan tersebut antara lain,:1) Balai Setia Hukama; 2) Balai Setia Ulama; dan 3) Balai Jamiah Himpunan Ulama, yakni semacam Studi Club atau tempat para Ulama berkumpul dan mendiskusikan masalah-masalah pendidikan dan pengajaran serta pengembangan Ilmu Pengetahua.

Dalam rangka mencerdaskan rakyat kerajaan Aceh Darussalam membangun saranasarana pendidikan untuk semua tingkatan pendidikan: meunasah (setingkat SD atau madrasah Ibtidaiyah), Rangkang (setingkat SLTP) atau madrasah Tsanawiyah), Dayah (setingkat SMU dan madrasah Aliyah), dayah tgk Chik (setingkat Perguruan Tinggi/akademi), Jami'ah Baiturrahman (fakultas).

Di zaman kerajaan Aceh Darussalam, ibukota Banda Aceh merupakan pusat kegiatan pendidikan, kebudayaan, dan ilmu pengetahuan Asia Tenggara, pada saat itu ada tiga tempat yang menjadi pusat ilmu pengetahuan, yaitu mesjid Baiturrahim, mesjid Baitul Musyahadah, dan mesjid Jami' Baiturrahman. Banyak pelajar datang menuntut Ilmu ke Aceh baik dari Minangkabau maupun dari Asia Tenggara. Sebuah Qanun yang mengatur para pelajar dari luar Aceh di buat dengan membubuhkan sebuah pasal yang khusus mengatur hal tersebut. ${ }^{5}$

Sejalan dengan perkembangan pendidikan pada masa Sultan Iskandar Muda, berkembang pula kebudayaan di kerajaan Aceh, terutama dalam bidang kesusastraan. Di bidang ini, Aceh telah menjadi pusat pengembangan kesusastraan Melayu pada umumnya. Berbagai buku ilmu pengetahuan dan kesusastraan yang dihasilkan, dari masa kepemerintahan sultan Iskandar Muda, terdiri dari buku-buku yang berbahasa Aceh, Melayu atau bahasa Arab. Buku-buku tersebut memuat berbagai bidang kajian, seperti sejarah, agama dan sastra, buku-buku yang dihasilkan pada masa ini antara lain merupakan tulisan yang memiliki nilai-nilai sejarah, misalnya hikayat Malem Dagang, sebuah epos yang menceritakan kehidupan Iskandar Muda: penyerangan ke Johor, kegiatan dalam pemerintahan, keadaan istana kerajaan, kemajuan kerajaan Aceh secara umum pada saat itu. Dari sekian banyak buku-buku agama dan bukubuku sastra yang sampai sekarang naskahnya masih dijumpai, sebagian besar berasal dari masa keemasan kerajaan Aceh. ${ }^{6}$

Pada masa Iskandar Muda terdapat tiga bahasa resmi yang berkembang di Aceh, yaitu bahasa Aceh, Bahasa Melayu dan bahasa Arab. Ketiga bahasa tersebut memiliki fungsi yang berbeda. Bahasa Aceh merupakan bahasa nasional Kerajaan Aceh Darussalam dan lazim dipergunakan oleh rakyat dalam pergaulan seharihari. Bahasa Melayu adalah bahasa yang paling banyak digunakan dalam komunikasi di kerajaan Aceh masa Iskandar Muda, bahasa ini memiliki beberapa fungsi yaitu: Pertama, Bahasa istana; kedua, Bahasa Sarakata, ketiga, Bahasa ilmu pengetahuan; keempat, Bahasa pengantar pengajaran; kelima, Bahasa pengucapan pasaran; keenam, Bahasa penghubung antara wilayah kerajaan; ketujuh, Bahasa media dakwah; kedelapan, Bahasa diplomasi; dan kesembilan, Bahasa surat menyurat.

Bahasa Arab dijadikan sebagai bahasa resmi, karena bahasa ini merupakan bahasa agama yaitu Al-Qur`an dan Hadits, bahasa bacaan dalam shalat dan bahasa azan. Selain itu bahasa Arab juga berfungsi sebagai bahasa penghubung antar ulama, bahasa pengantar pada dayah-

\footnotetext{
${ }^{5}$ Safwan Idris, Pendidikan di Aceh, (Banda aceh majelis pendidikan daerah,1975), 110.
}

${ }^{6}$ Sanusi Pane, Sejarah pekembangan Indonesia, (Jakarta:Balai Pustaka, 2002 ), 130. 
dayah di tingkat menengah atas, bahasa ilmu pengetahuan dan bahasa penghubung antara negara-negara Islam.

Pada masa sultan Iskandar Muda dalam Kerajaan Aceh Darussalam telah muncul sejumlah ulama dan pengarang yang menyusun berbagai kitab dalam bermacam ilmu pengetahuan, baik dalam bahasa Melayu maupun bahasa Arab, kitab-kitab karangan mereka meliputi bidang ilmu fikih, tauhid/filsafat, tasawuf, akhlak, ilmu falak, mantiq, sejarah Islam dan bahasa Arab. Kitab-kitab ini dipergunakan menjadi bacaan di sekolahsekolah dari berbagai jenjang pendidikan, baik meunasah, rangkang, dayah, teungku chik, ataupun di Jami'ah Baiturrahman. Dan kitab-kitab mereka dipergunakan sebagai buku pelajaran agama Islam di seluruh kepulauan nusantara yang berbahasa Melayu. ${ }^{7}$

Sejak pecahnya perang melawan Belanda pada tahun 1873, dayah di Aceh memegang peran penting dalam pengerahan tenaga pejuang, terutama murid dan masyarakat di sekitar dayah ke medan peperangan. Dalam menumbuhkan semangat juang rakyat melalui motivasi keagamaan, seperti ajakan perang sabil, dayah berperan sangat besar, karena itu tidak mengherankan jika pada akhir abad ke 19 banyak dayah yang terbengkalai akibat serangan Belanda yang menganggap dayah sebagai konsentrasi para pejuang, baru setelah perang mereda, para Teungku Chik yang tersisih berusaha membangun kembali dayah yang terlantar selama ini.

Pada saat itu semua dayah mengalihkan aktivitasnya ke arah perjuangan politik melawan Belanda di samping mengajarkan ilmu agama. Ketika Belanda menaklukkan Aceh, lembaga pendidikan dayah menjadi dwi fungsi, selain mengajarkan ilmu pengetahuan agama juga menjadi tempat mendidik sikap patriotisme bagi para pemuda, sekaligus menjadi tempat latihan militer untuk menghadapi penjajah Hindia Belanda. Ketika Belanda berhasil menguasai sebagian wilayah di Aceh, mereka menetapkan peraturan untuk pendirian dayah. ${ }^{8}$

Namun demikian, lembaga pendidikan dayah tetap terpelihara dengan sistemnya yang khas. Ketika Belanda masuk ke Aceh mereka mendirikan lembaga pendidikan sekolah dengan mengajarkan ilmu umum dan menerapkan sistem yang berbeda, hal ini dilakukan sebagai penyeimbang terhadap lembaga pendidikan dayah yang berorientasi kepada pendidikan agama. Sejak perang itu berkecamuk, banyak tenaga ulama yang gugur, karena syahid di medan perang, seperti Teungku Chik Di Tiro, Tgk di Keumala, Hal itu berlangsung sampai tahun 1912.

Setelah Indonesia merdeka penuh dari Belanda, pendidikan menjadi hak setiap rakyat, pemerintah berusaha menyelenggarakan pendidikan yang dapat diakses oleh setiap rakyat. Namun demikian pendidikan agama belum mendapat tempat yang layak di dalam sistem pendidikan nasional, dengan perjuangan yang gigih oleh para cendekiawan muslim maka pendidikan agama mendapat tempat dalam sistem pendidikan nasional. Satu-satunya lembaga pendidikan yang diakui resmi oleh negara pada saat itu yaitu lembaga pendidikan sekolah. Sekolah merupakan anak emas pemerintah, segala fasilitas baik sarana maupun prasarana semua sediakan oleh pemerintah. Kurikulum yang berlaku di sekolah adalah kurikulum nasional yang disusun oleh kementrian pendidikan. Pelajaran agama hanya diajarkan dua jam seminggu, selebihnya adalah pelajaran umum yang terdiri dari pengetahuan sosial dan pengetahuan alam. Jam belajar siswa hanya pada pagi hari, para siswa sekolah tidak diasramakan, mereka belajar hanya pada pagi hari, kemudian pulang. Sedangkan interaksi dengan guru hanya terjadi pada pagi hari.

Madrasah sebagai lembaga pendidikan dalam bentuk pendidikan formal sudah dikenal sejak awal abad ke-11 atau $12 \mathrm{M}$ atau abad ke 5-6 $\mathrm{H}$, yaitu sejak dikenal adanya madrasah

${ }^{7}$ Kamaruzzaman, dan Bustaman Ahmad, Pdf Jurnal Ilmiah Peuradeun, (.tt: t.p., t.h.), 180.

${ }^{8}$ Ali Hasyimy, Pendidikan Islam di Aceh Dalam Perjalanan sejarah, (Banda Aceh: Sinar Darussalam, 1975$), 79$. 
Nizamiyah yang didirikan di Bagdad oleh Nizam Al-Mulk, seorang wazir pada masa dinasti Saljuk. Di Indonesia, Madrasah merupakan fenomena modern yang muncul pada awal abad ke 20 berbeda dengan di timur tengah di mana madrasah sebagai lembaga pendidikan yang memberikan pelajaran ilmu agama tingkat lanjut, sebutan madrasah di Indonesia mengacu pada lembaga pendidikan yang memberikan pelajaran agama Islam tingkat rendah dan menengah. Perkembangannya diperkirakan lebih merupakan reaksi terhadap faktor-faktor yang berkembang dari luar lembaga pendidikan yang secara tradisional sudah ada, terutama munculnya pendidikan modern Barat. Dengan perkataan lain, tumbuhnya madrasah di Indonesia adalah hasil tarik menarik antara pesantren sebagai lembaga pendidikan asli (indengius Calture/tradisional) yang sudah ada di satu sisi, dengan pendidikan barat di sisi lain. Dalam dinamika seperti ini maka didirikanlah madrasah. ${ }^{9}$

\section{Perkembangan bahasa Arab di Sumatera}

Berkembangnya bahasa Arab di Sumatera di buktikan dengan adanya lembaga atau tempat pembelajaran, dan lembaga tersebutlah yang bersinergi memberikan pendidikan Islam, tentunya mukarrornya atau pelajarannya tidak lepas dari bahasa Arab.

a. Masjid, Langgar, Surau dan Meunasah

Pada awalnya, pendidikan Islam yang paling sederhana seluruhnya dipusatkan pada Alquran dan disebut pengajian Alquran. Dalam pengajian ini murid belajar huruf-huruf Arab dan menghafalkan ayat-ayat yang terdapat dalam Alquran. Di samping itu, diajarkan pula aturan-aturan dan tata cara sholat, wudhu' dan doadoa. Lembaga awal pengajian ini dilakukan secara individual di rumah guru, masjid, langgar, atau surau. Namun ada juga dilakukan di rumah-rumah orang tua murid yang memiliki kedudukan penting.

Selain masjid dan langgar digunakan sebagai tempat melaksanakan shalat lima waktu, juga digunakan untuk tempat pendidikan bagi orang dewasa dan anak-anak. Pengajian yang dilakukan untuk orang dewasa adalah penyampaian-penyampaian ajaran Islam oleh para ustadz, guru maupun kyai kepada para jama'ah dalam bidang aqidah, ibadah, syari'ah dan akhlak. Sedangkan pengajian yang dilaksanakan untuk anak-anak berpusat pada pengajian Alquran yang menitikberatkan pada kemampuan anak membacanya dengan baik dan benar sesuai kaidah-kaidah bacaannya. Selain itu anak-anak juga diberikan ilmu keimanan yang bertumpuh pada rukun iman yang enam, ilmu ibadah seperti tata cara shalat dan akhlak dalam kehidupan sehari-hari.

Pendidikan agama Islam di langgar bersifat elementer, dimulai dari mempelajari abjad huruf Arab sebagai pengenalan awal tentang isi Alquran sambil mengikuti gurunya, anak-anak belajar dengan duduk bersila dan belum memakai meja dan bangku. Pengajian Alquran dilanggar bertujuan agar anak didik dapat membaca Alquran berirama dan baik dan belum ditekankan untuk mengetahui tentang isi Alquran.

Selain masjid, kita juga mengenal istilah surau. Pada mulanya surau di kenal di daerah Sumatera Barat sebelum Islam masuk merupakan tempat bertemu, berkumpul, rapat, dan tempat tidur bagi anak laki-laki yang telah akil baligh dan orang tua yang sudah uzur. Setelah mengalami Islamisasi surau masih dijadikan sebagai tempat menginap anak lakilaki, tetapi bertambah luas fungsinya sebagai tempat pengajaran dan pengembangan ajaran-ajaran Islam, seperti menjadi tempat shalat membaca Alquran dan sebagainya. ${ }^{10}$

\footnotetext{
${ }^{9}$ Ibid, 120.

${ }^{10}$ safwan Idris, Pendidikan di Banda Aceh, (Majelis Pendidikan Daerah, 1998), 60.
} 
Sampai sekarang ini kita mengenal istilah surau merupakan sebagai tempat shalat yang bangunannya lebih kecil dari masjid, dan hanya digunakan sebagai shalat berjamaah lima waktu sehari semalam tidak untuk shalat jumat, serta sebagai tempat mengaji anak-anak belajar membaca Alquran. Di daerah Aceh muncul istilah meunasah, secara etimologi istilah meunasah berasal dari bahasa Arab yakni madrasah yang berarti tempat belajar. Seiring perjalanan waktu kata madrasah itu oleh masyarakat Aceh berobah menjadi meunasah.

Secara terminology meunasah adalah tempat untuk shalat dan juga digunakan untuk belajar tentang ilmu keislaman pada tingkat dasar termasuk orang yang baru belajar membaca Alquran.

Lembaga-lembaga pendidikan Islam awal seperti rumah-rumah ustadz, langgar, masjid, surau dan meunasah menjadi embrio terbentuknya sistem pendidikan Islam yang formal, yakni pesantren, madrasah dan sekolah yang berdasarkan keagamaan. Hal ini karena masjid sudah tidak mampu menampung lagi umat Islam yang ingin belajar dan mendalami tentang Islam lebih jauh, maka diperlukan sebuah lembaga yang lebih luas sehingga mampu mengakomodir semua kegiatan dan keinginan umat Islam tersebut. Dengan adanya sebuah lembaga yang luas, maka umat Islam akan lebih berkonsenterasi untuk belajar, memiliki waktu yang cukup banyak dan tidak mengganggu kekhusyukan orang untuk beribadah. ${ }^{11}$

b. Pondok Pesantren

Pondok pesantren adalah tempat Pendidikan Islam yang mengkaji kitab kuning yang berbahasa Arab.

Syekh Nawawi bin Umar Al-bantani Al-jawi pada abad pertengahan mengatakan

Adapun tujuan pembelajaran kitab kuning adalah:

1. Agar santri mengetahui dan memahami isi kitab yang telah diwariskan oleh para ulama yang di dalamnya berisikan penjelasan tentang Al-Qur'an dan hadits dengan terlebih dahulu mempelajari ilmu alatnya yaitu ilmu nahwu dan sharaf.

2. Agar santri mampu mengaplikasikan isi kitab kuning seperti

ilmu fiqh, tafsir dan hadits kepada masyarakat yang menjadi objek sasaran dakwah dengan mengedepankan hukum Islam, atau madzhab fiqih tertentu sebagai sumber hukum, baik secara historis maupun secara resmi.

3. Tujuan selanjutnya adalah menjadi penerus para ulama dalam berdakwah dan menyiarkan hukum-hukum Islam.

Dari sini kita dapat menyimpulkan bahwa, pembelajaran bahasa Arab di sumatera telah di mulai sejak dahulu kala, hal ini dibuktikan dengan adanya tempat belajar yang berupa pondok Pesantren, masjid, Langgar,Surau dan meunasah. Tempat-tempat inilah yang di gunakan untuk mengajarkan bahasa Arab, mulai dari pelafalan huruf-hurufHijaiyah dan Do'a Wudu' hingga Solat.

\section{Metode Pembelajaran Teks Kitab Kuning di Pondok Pesantren}

Dalam pembelajaran teks kitab kuning, perlu juga diperkenalkan beberapa metode pembelajaran agar mudah dalam memahaminya. Metode pembelajaran teks kitab kuning yang menjadi ciri utama proses pembelajaran adalah sebagai berikut:

a. Metode Bandongan (Collective Learning Process)

${ }^{11}$ Ibid, 120. 
Metode Bandongan atau metode wetonan, dikenal dengan metode layanan kolektif (collective learning process), yaitu metode pembelajaran yang disampaikan secara langsung oleh ustadz terhadap sekelompok peserta didik, untuk mendengarkan dan menyimak apa yang dibacakan atau diterjemahkan dari sebuah kitab tertentu. Dalam pola pembelajaran ini ustadz membacakan manuskrip keagamaan klasik yang berbahasa arab (Kitab Kuning) yang berlangsung di pesantren, sementara para santri mendengarkan secara seksama sambil lalu memberi catatan pada kitab yang sedang dibaca. ${ }^{12}$

Metode bandongan, biasanya diterapkan ustadz dalam membaca teks kitab kuning, ustadz menerangkan kalimat demi kalimat dan menerjemahkan dengan menggunakan bahasa setempat. Santri secara cermat mendengar, mengikuti bacaan dengan penjelasan yang diberikan ustadz. Cara-cara seperti itu santri membuat catatan-catatan tertentu pada kitabnya masing-masing atau kode kode tertentu sehingga kitabnya disebut kitab jenggot. Belajar dengan metode bandongan ini, "lama belajar santri tidak tergantung lamanya tahun belajar tetapi berpatokan kepada waktu kapan murid tersebut menamatkan kitabnya yang telah ditetapkan". ${ }^{13}$

Kitab-kitab kuning berteks ini, ditulis oleh ulama-ulama Islam pada zaman pertengahan. Kepintaran dan kemahiran santri diukur dari kemampuannya membaca, serta mensyarahkan (menjelaskan) isi kitab-kitab tersebut. Kegiatan pembalajaran teks kitab kuning biasanya dengan menggunakan metode bandongan. ini:

Langkah-langkah pelaksanaannya adalah berikut ini: pelaksanaannya adalah berikut

1. Seorang ustadz menciptakan komunikasi yang baik dengan para santri.

2. Memperhatikan situasi dan kondisi serta sikap para santri apakah sudah siap untuk belajar atau belum.

3. Pada pembelajaran ditingkat yang lebih tinggi, seorang ustadz terkadang tidak langsung membaca dan menterjemahkan isi kitab. Ia terkadang menunjuk secara bergiliran kepada para santrinya untuk membaca dan menterjemahkan sekaligus menerangkan suatu teks tertentu. Disini ustadz sering berperan sebagai pembimbing yang membetulkan apabila terdapat kesalahan dan menjelaskan bila ada hal-hal yang dipandang oleh para santri sebagai sesuatu yang asing atau rumit.

4. Setelah menyelesaikan pembacaan pada batasan tertentu, seorang ustadz memberi kesempatan kepada para santri untuk menanyakan hal-hal yang belum jelas. Jawaban dilakukan langsung oleh ustadz atau memberi kesempatan terlebih dahulu kepada para santri yang lain.

5. Sebagai penutup ustadz memberikan kesimpulan-kesimpulan yang dapat ditarik dari kegiatan pembelajaran yang telah berlangsung. 25

Pembelajaran kitab-kitab kuning dipandang penting oleh dayah, karena dapat menjadikan santri menguasai dua materi sekaligus.

Pertama, bahasa Arab yang merupakan bahasa kitab itu sendiri. Kedua, pemahaman atau penguasaan muatan dari kitab tersebut. Dengan demikian, seorang santri yang telah menyelesaikan pendidikannya di pesantren sudah mampu memahami isi kitab secara baik, sekaligus dapat menerapkan bahasa kitab tersebut menjadi bahasa kesehariannya.

\footnotetext{
12 Tim Direktorat Jendral Kelembagaan Agama Islam, Pola Pembelajaran di Pesantren, (Jakarta: Departemen Agama RI, Direktorat Jendral Kelembagaan Agama Islam, Direktorat Pendidikan Keagamaan dan Pondok Pesantren, Proyek Peningkatan pendidikan Luar sekolah pada Pondok Pesantren, 2003), 91.

${ }^{13}$ Zamakhsyari Dhofier, Tradisi Pesantren Studi Tentang Pandangan Hidup Kyai. (Jakarta: LP3ES, 1994$), 55$.
} 
b. Metode Sorogan (Individual Learning Process)

Metode sorogan terdiri dari dua suku kata yaitu metode dan sorogan. Metode berarti cara atau jalan yang dilalui untuk mencapai tujuan. Sedangkan kata sorogan berarti menyodorkan, dalam tulisan ini yang disodorkan adalah kitab kuning. ${ }^{14}$

Pengertian metode sorogan menurut Armain Arif yang mengutip pendapat dari Mastuhu dalam Pengantar Ilmu dan Metodologi Pendidikan Islam adalah menjelaskan bahwa sorogan artinya belajar secara individu di mana seorang santri berhadapan dengan seorang guru atau kyai, terjadi interaksi saling mengenal di antara keduannya.

Hasbullah menyebut sorogan sebagai cara mengajar per-kepala, yaitu setiap santri mendapat kesempatan tersendiri untuk memperoleh pelajaran secara langsung dari ustadz.

Penerapan metode sorogan mau tidak mau harus terjadi interaksi antara dua individu, yakni ustadz dan santri. Interaksi dari keduanya dapat terjadi jika ustadz membaca atau berbicara sedang santri mendengarkan atau menyimak ataupun santri membaca atau berbicara sedang ustadz mendengar atau menyimak.

Hasbullah menggambarkan bahwa pelaksanaan pembelajaran yang menggunakan metode sorogan ini, santri bersama-sama mendatangi ustadz, kemudian mereka antri dan menunggu giliran masing-masing. ${ }^{15}$

Dari gambaran tersebut dapat diketahui bahwa metode sorogan membutuhkan keaktifan dan kesiapan santri.

Di lain pihak, Zamakhsyari Dhofier berpendapat bahwa metode sorogan ini merupakan bagian yang paling sulit dari keseluruhan metode pendidikan Islam tradisional, sebab sistem ini menuntut kesabaran, kerajinan, ketaatan, dan disiplin pribadi santri. ${ }^{16}$

c. Metode Halaqah

Yang dimaksud halaqah di sini adalah sekelompok santri yang belajar di bawah bimbingan seorang ustadz yang belajar bersama dalam satu tempat untuk mendiskusikan pemahaman terhadap suatu masalah atau suatu kitab tertentu.

Metode Halaqah, dikenal juga dengan istilah munazaharah merupakan kelompok kelas dari metode wetonan. Halaqah secara bahasa berarti lingkaran murid atau sekelompok siswa yang belajar dibawah bimbingan seorang guru, atau belajar bersama dalam satu tempat. Metode ini merupakan diskusi untuk memahami isi kitab, bukan untuk mempertanyakan kemungkinan benar salahnya apa-apa yang diajarkan oleh kitab, tetapi untuk memahami apa maksud yang diajarkan oleh kitab tersebut. ${ }^{17}$

d. Hiwar atau Musyawarah

Metode hiwar atau musyawarah, hampir sama dengan metode diskusi yang umum kita kenal selama ini. Bedanya metode hiwar dilaksanakan dalam rangka pendalaman atau pengayaan materi yang sudah ada di santri. Yang menjadi ciri khas dari hiwar ini, santri dan ustadz biasanya terlibat dalam sebuah forum perdebatan untuk memecahkan masalah yang ada dalam kitab-kitab yang sedang dipelajari santri. ${ }^{18}$

e. Metode Bahtsul Masa'il (Mudzakarah)

Metode Bahtsul Masa'il merupakan metode pembelajaran yang lebih mirip dengan metode diskusi atau seminar ilmiah yang membahas masalah diniyah, seperti ibadah, aqidah, dan masalah agama pada umumnya. Beberapa orang santri dengan jumlah

\footnotetext{
${ }^{14}$ Armai Arif, Pengantar Ilmu dan Metodologi Pendidikan Islam, (Jakarta: Ciputat Press, 2002), 150.

${ }^{15}$ Hasbullah, Sejarah Pendidikan Islam di Indonesia: Lintasan Sejarah Pertumbuhan dan Perkembangannya, (Jakarta:

PT. Raja Grafindo Persada, 1995), 145.

${ }^{16}$ Zamakhsyari Dhofier, Tradisi Pesantren: Studi tentang Pandangan Hidup Kyai, (Jakarta: LP3ES, 1982$), 108$.

17 Zuhairini,dkk, Metodik Khusus Pendidikan Agama, (Malang:Biro Ilmiah Fakultas Tarbiyah IAIN Sunan Ampel,1981), 68.

${ }^{18}$ Ibid. 69.
} 
tertentu membentuk halaqoh yang dipimpin langsung oleh ustadz, atau mungkin juga santri senior, untuk membahas atau mengkaji suatu persoalan yang telah ditentukan sebelumnya. ${ }^{19}$

\section{KESIMPULAN}

Bahasa Arab adalah bahasa yang sangat mulia dan memiliki keistemewaan yang sangat banyak dibandingkan dengan bahasa lainnya. Bahasa Arab sebagai bahasa agama islam adalah sebuah fakta yang tidak dapat dipungkiri. Karena dengan Bahasa Arablah agama ini ditegakkan, dan alqura'an diturunkan. Bahsa Arab adalah bahasa yang memiliki keunggulan, keberagaman serta kekayaan perbendaharaan kosakata yang sangat banyak dibandingkan dengan bahsa lainnya. Bahasa Arab telah menjadi pengantar resmi masyarakat indonesia, hususnya di pulau Sumatera, ditemukan banyak kata sarapan bahasa Arab yang terdapat dalam bahasa Indonesia.

pada masa kesultanan Aceh adalah lembaga pendidikan zawiyah (dayah), lembaga pendidikan ini menganut sistem pendidikan zawiyah di timur tengah yang dibawa oleh ulama-ulama yang membawa Islam ke Aceh. Pada masa itu lembaga pendidikan ini telah mengharumkan nama Aceh dengan melahirkan ulama-ulama yang bertaraf internasional, menghasilkan berbagai karya yang menjadi rujukan dalam ilmu-ilmu keislaman dan menjadi pusat ilmu pengetahuan di Asia Tenggara.

Pada masa Iskandar Muda terdapat tiga bahasa resmi yang berkembang di Aceh, yaitu bahasa Aceh, Bahasa Melayu dan bahasa Arab. Ketiga bahasa tersebut memiliki fungsi yang berbeda. Bahasa Aceh merupakan bahasa nasional Kerajaan Aceh Darussalam dan lazim dipergunakan oleh rakyat dalam pergaulan sehari-hari. Bahasa Melayu adalah bahasa yang paling banyak digunakan dalam komunikasi di kerajaan Aceh masa Iskandar Muda, bahasa ini memiliki beberapa fungsi yaitu: Pertama, Bahasa istana; kedua, Bahasa Sarakata, ketiga, Bahasa ilmu pengetahuan; keempat, Bahasa pengantar pengajaran; kelima, Bahasa pengucapan pasaran; keenam, Bahasa penghubung antara wilayah kerajaan; ketujuh, Bahasa media dakwah; kedelapan, Bahasa diplomasi; dan kesembilan, Bahasa surat menyurat.

Bahasa Arab dijadikan sebagai bahasa resmi, karena bahasa ini merupakan bahasa agama yaitu Al-Qur`an dan Hadits, bahasa bacaan dalam shalat dan bahasa azan. Selain itu bahasa Arab juga berfungsi sebagai bahasa penghubung antar ulama, bahasa pengantar pada dayah-dayah di tingkat menengah atas, bahasa ilmu pengetahuan dan bahasa penghubung antara negara-negara Islam.

Pada masa sultan Iskandar Muda dalam Kerajaan Aceh Darussalam telah muncul sejumlah ulama dan pengarang yang menyusun berbagai kitab dalam bermacam ilmu pengetahuan, baik dalam bahasa Melayu maupun bahasa Arab, kitab-kitab karangan mereka meliputi bidang ilmu fikih, tauhid/filsafat, tasawuf, akhlak, ilmu falak, mantiq, sejarah Islam dan bahasa Arab. Kitab-kitab ini dipergunakan menjadi bacaan di sekolahsekolah dari berbagai jenjang pendidikan, baik meunasah, rangkang, dayah, teungku chik, ataupun di Jami'ah Baiturrahman. Dan kitab-kitab mereka dipergunakan sebagai buku pelajaran agama Islam di seluruh kepulauan nusantara yang berbahasa Melayu. Arab.

Adannya beberapa lembaga yang mengajarkan pendidikan dengan pelajaran yang berbahsa

1) Masjid, Langgar, Surau dan Meunasah sebagai tempat pembelajaran agama dan pembelajaran bahasa Arab.

2) Pondok pesantren.

\footnotetext{
${ }^{19}$ Fakultas Tarbiyah IAIN Wali Songo, Metodologi Pengajaran Agama, (Semarang: Pustaka Pelajar, 2004), 4.
} 
Sebagai tempat para santri untuk smenuntut ilmu agama dan belajar bahsa Arab dengan menggunakan kitab kuning sebagai mukarror.

Lembaga Pondok Pesanteren memiliki beberapa metode mebelajaran bahasa Arab

$\checkmark$ Metode Bandong

$\checkmark$ Metode Sorong

$\checkmark$ Metode Halaqah

$\checkmark$ Metode Hiwar atau Musyawarah

$\checkmark$ Metode Bahtsul Masa'il

\section{DAFTAR PUSTAKA}

Ali, Lukman. 1994. Kamus Besar Bahasa Indonesia. Jilid II, Departemen P \& K RI. Jakarta: Balai Pustaka.

Arif,Armai. 2002. Pengantar Ilmu dan Metodologi Pendidikan Islam.Jakarta: Ciputat Press.

Dhofier,Zamakhsyari1982. Tradisi Pesantren: Studi tentang Pandangan Hidup Kyai. Jakarta: LP3ES.

Hasbullah. 1995. Sejarah Pendidikan Islam di Indonesia: Lintasan Sejarah Pertumbuhan dan Perkembangannya. Jakarta: PT. Raja Grafindo Persada.

Hasymy, Ali. 1975. Pendidikan Islam di Aceh Dalam Perjalanan Sejarah. Banda Aceh: Sinar Darussalam.

Idris, Safwan. 1998. Pendidikan di Aceh. Banda Aceh. Majelis Pendidikan Daerah.

Islam, Tim Direktorat Jendral Kelembagaan Agama. 2003. Pola Pembelajaran di Pesantren. Jakarta: Departemen Agama RI, Direktorat Jendral Kelembagaan Agama Islam, Direktorat Pendidikan Keagamaan dan Pondok Pesantren, Proyek Peningkatan pendidikan Luar sekolah pada Pondok Pesantren.

Kamaruzzaman dan Ahmad, Bustam. Pdf Jurnal Ilmiah Peuradeun: .tt: t.p., t.h.

Nuha, Ulin. 2016. Ragam Metodelogi Dan Media Pembelajaran Bahasa Arab.Yogyakarta:

Diva Perss.

Pane, Sanusi. 1995. Sejarah Perkembangan Indonesia. Jakarta: Balai Pustaka.

Songo, Fakultas Tarbiyah IAIN Wali. 2004. Metodologi Pengajaran Agama. Semarang: Pustaka Pelajar.

Zuhairini, dkk. 1981. Metodik Khusus Pendidikan Agama. Malang: Biro Ilmiah Fakultas Tarbiyah IAIN Sunan Ampel. 